\title{
The Danish Cartoons, Charlie Hebdo and the culture wars: satiric limits in comparative national and transnational perspectives
}

\author{
Mark John Rolfe \\ University of New South Wales, Australia \\ m.rolfe@unsw.edu.au
}

\begin{abstract}
A considerable body of academic literature has lauded political satirists as rebellious defenders of democracy and free speech against an establishment. Although satire is not always rebellious, this reputation of satirists and of satire may itself be the object of partisan capture. In this article, it is the object of capture by right-wing populists. In that respect, satire and the metadiscourse about satire can be used like any political rhetoric in gathering like-minded allies, claiming standards, and fighting opponents. With the Danish cartoons crisis of 2005-2006 and the Charlie Hebdo massacre of 2015, proponents of culture wars rhetoric added satire to their list of Western cultural legacies that needed defence against Islamic terrorism as well as left authoritarian elites who suppressed free speech through political correctness. They constructed simplistic global political dichotomies about satire, free speech, and civilisation and lifted events out of local contexts in a process of global framing. The culture war rhetoric was absolutist in support of free speech and satire on the international level. But the national level reveals the hortatory and partisan side to this rhetoric and the complexities that belie the absolutist stand. Nations are the arenas where struggles over free speech and political humour are played out.
\end{abstract}

Keywords: satire, culture wars, rhetoric, Australia, Israel, America, populism, Charlie Hebdo, Danish cartoons, free speech.

\section{Introduction}

Horror at the savagery could not be contained. Millions of people took over the streets of Paris and other French cities to demonstrate grief and unity after the slaughter at the Charlie Hebdo offices. Millions more across the world expressed sympathy and solidarity through the Twitter hashtag \#JeSuisCharlie. Media across the political spectrum shared this tag and the view that the attack was an assault on liberty and freedom of speech. Also flashing across television screens that weekend in January 2015 was the inspiring image of forty world leaders marching 
arm-in-arm to the Place de la Nation in the name of free speech. Famed historian Simon Schama (2015) wrote:

Liberty and laughter have been twinned in the European tradition for more than three centuries and have together proclaimed as precious the right to ridicule. [...] Though the self-righteous have killed the satirists they will never annihilate satire itself. Just the opposite. From now on, Charlie Hebdo will be the rallying point for all those who cherish life and laughter over the death-cult of sanctimonious gloom.

Behind the façade of international unity around freedom of speech were other stories that complicated the photo-ops of that day. The following day British Prime Minister David Cameron started the legislative process that allowed tracking of all British citizens without any need for judicial checks (Watt et al. 2015; Wintour \& MacAskill 2015). US President Barack Obama was represented by Attorney-General Holder who was in dispute with Julian Assange over the release of State Department records. Advancing his attack on President Mahmoud Abbas of Palestine for abetting terrorism, Prime Minister Benjamin Netanyahu of Israel used the Hebdo massacre to sway sympathy his country's way by stating that "Europe must stand with Israel" since they faced the same enemy in radical Islam. Despite this vaunted stand Reporters Without Borders had stated: "The Israeli media is able to be outspoken but media located in "Israeli territory" must comply with prior military censorship and gag orders. Investigative reporting involving national security is not welcome." Equally, Amnesty International said of the Palestinian Authority: "Both the PA and Hamas maintained tight restrictions on freedoms of expression, association and assembly, harassing and prosecuting journalists, bloggers and other critics" (Walker et al. 2015).

Charlie Hebdo and the freedom to ridicule did become a rallying point but not in the universal way Schama (2015, see above) envisaged. The magazine became in part a partisan rallying point. It was added to the Danish cartoons incident of 2006 and a string of other satiric events outlined in this article, thereby acquiring totemic significance in international right-wing populist rhetoric of the culture wars about identity politics and political correctness. These populists compiled these incidents into an international narrative of struggle on the global stage against the politically correct left who are generally undermining Western civilisation, The Enlightenment, and freedom of speech. Within their own countries populists added this plausible but contentious international rhetoric to their domestic hortatory rhetoric of partisan politics between left and right, especially in Anglosphere nations such as Australia. There Charlie Hebdo and other examples of satire became handy and simplistic slogans.

This rhetoric plays out more simplistically across the globe where it is useful for sorting like-minded political allies than it does within nations where the complexities of satire and free speech reside. The problem is that the nation-state is the primary arena of struggle over the standards and demarcations of free speech and humour and where the meta-discourse of humour is conducted in all its complexity rather than in the vagaries of the international arena. As much as the nation-state is an imagined community, to borrow the words of Anderson (2006), it is also conceived as a realm of political and legal sovereignty that constructs the arena in which such struggles take place, especially through party and partisan battles. The national level demonstrates the intricacies that belie the absolutist stand for free speech asserted in the international rhetoric. Free speech and humour are not fixed universal principles that exist outside of the vagaries and contexts of human life. Instead, their meanings emerge through the continual social dispute and argument of a community in its context and time. This argument, then, is concerned with the meta-discourse of humour (Billig 2005: 185) and with the effects among different publics when satire and indignation are mobilised (Phiddian 2019: 4, 14) for political identity. 
Such intricacies were displayed, for instance, less than a week after the Hebdo massacre. French police arrested a teenager for allegedly defending terrorism because he posted on Facebook a parody of a 2013 Hebdo cartoon that mocked the killing of Egyptian protesters with the punch line "The Quran is shit. It doesn't stop bullets." In the parodic version, a Hebdo cartoonist supplants the protester and the punch line is "Charlie Hebdo is shit. It doesn't stop bullets" (Abunimah 2015; Turgis 2015). This cartoon originated on the website of French comedian Dieudonné M'bala M'bala whose anti-Semitic utterances align with elements of National Rally (previously Front National). Four days after the marches, French police arrested him as an "apologist for terrorism" for statements about one of the gunmen. Near the end of 2015 he was convicted of anti-Semitic utterances in Belgium (BBC 2015). Clearly, absolute free speech did not exist at such a sensitive time for French authorities. Nevertheless, justification or criticism of these arrests and of the limits of free speech can only be understood with the French political context, with particular reference to nationalism, republicanism, anti-Semitism, and the far right.

Given such instances, it is necessary to consider what are called the humour taste cultures (Davis 2016: 199) or humour regimes of societies. Kuipers (2011: 69) defines the latter as "discursive regimes" of "unwritten rules stipulating who can joke about what" and "declar[ing] some topics off-limits." Therefore, they also specify boundaries, power relations, "and endow some with more rights to speak in jest than others." Rhetorical engagements and contentions within societies are the means for such regimes to exist, which involve not only humour itself but also the rhetoric or meta-discourse about the humour. Such discussions, which are sometimes polemical and political, constitute the movable and contested frontier between laughter and unlaughter, which is the expression of disapproval on an occasion when humour is attempted (Billig 2005: 183, 197-200).

Kuipers (2011: 69) has previously examined how a humour scandal (i.e. the Danish cartoons crisis) in "a national public sphere with a well-established (though not uncontested) regime governing public humour" was transplanted into "a conflicted and contested transnational public space less equipped to deal with humour scandals." Similarly, this paper uses examples of political satire and issues of religion and race transmitted from the international to national levels to illuminate the clashing rhetoric over boundaries, conventions, political identities and partisan political positions.

\section{Satire and parrhesia}

My argument is at odds with persuasive assessments that satire is a rambunctious mode for rebels and underdogs who are on the margins taking humorous pot shots at the powerful. This sentiment is frequently summarised in the clichéd observation of satirists as "speaking truth to power." For instance, scholars have bestowed this accolade on Jon Stewart and Stephen Colbert as well as giving them radical reputations as Foucauldian parrhesiastes or truth-tellers (Warner 2010, 37; see also Boler \& Turpin 2008). In their analysis of Colbert, Tiboris \& Schaff (2009: 116-119) align the cliché and parrhesia "with democracy and the challenge to political authority," "political orthodoxy," and "majority public opinion." The two comedians were fearless tellers of uncomfortable truths taking on the powerful "corrupted by untruth" and "daring to say what the [mainstream media] would not" (Jordan 2008: 7, 9).

Such tributes, however, should be viewed in context rather than as definitive statements about satire. For Republican Party sympathisers, these views of Stewart and Colbert are arguable at best. For them, these two men and a host of late-night TV hosts were the purveyors of "smug liberalism" in 2015-2016 who, in the words of conservative satirist P. J. O'Rourke, forced a "rebellion against the elites" because of "the tremendous scorn for, and fun made of Trump and 
the Trump supporter" (Intelligence Squared 2016). This line of argument had slipped so neatly into established American culture war rhetoric that Ross Douthat (2016) of the New York Times and commentators at right wing outlets such as The Federalist (Hemingway 2016) and Nation Review (French 2017) mounted the same charge.

In this worldview, Trump is the comic rebel on behalf of ordinary people against the elites. He had even planted in some critics a sneaking admiration for his "comedic genius" that made for "an unexpectedly exhilarating experience, because amid the staid rules of politics his entire presence is refreshingly unpredictable" (Heer 2015). Another journalist admired the way he "skewers the American political system" and all of its "bullshit" (Reeve 2015). Indeed, these New Republic writers could not resist the mediated thrill Freud noticed with the humorous upending of societal constraints and the feelings of liberation from the psychological pressures to conform to those constrictions (Billig 2005: chapter 7).

In these contemporary populist times, there is something vicariously romantic and attractive about the rebel or parrhesiaste on the margins who is oppositional and defiant, thumbing their nose at the strictures of society, authority and orthodoxy. And this is all done in the name of truth and democracy. This persona and its narratives align with the anti-politics rhetoric, populism and historic tensions between rulers and ruled that are intrinsic to representative democracy (Rolfe 2016; cf. Canovan 1999). These common rhetorical assets are open to the resourcefulness of both left and right populists to deploy.

The significance of this communal knowledge (known in rhetoric as doxa) held by an audience in the right context (kairos) of a populist moment is that a satirist, like any rhetor, can have greater credibility and reputation (ethos) as an outsider on the margins than someone who can be plausibly damned as an insider with power. The rebel satirist may be listened to with greater favour than the despised establishment figure. Of course, the views of Stewart et al. as rebels have been contested and enough people have instead passed the appellation to Trump. As we shall see, the right in Australia have attempted to appropriate this rebel satirist ethos to their culture war struggles against a purported elite imposing its authoritarian designs.

I am incidentally arguing that "many satirists have been granted "truth-teller" status in serious and satiric realms of political commentary" (Higgie 2015: 74) yet there needs to be serious questioning of this allowance. After all, satirists should be examined like any rhetor aiming to convince an audience, and so should the application of the satiric ethos. I am therefore demonstrating that the notions of rebel satirist and powerful elite are contested relational concepts, as are the terms dominant and margins in this battle of rhetorical positioning. That is, they are terms that presuppose the existence of each other in order to supply meaning, what Zekavat calls relational identities (2017).

Certainly, as he maintains, marginalised Others have been often conceptualised through history as means of constructing ostensibly "normal" but perniciously dominant categories of race, gender, sexuality and ethnicity. These have excluded many who did not comply with such abstractions and satire has played a part in this rejection through maintaining certain humour regimes, their power hierarchies and their boundaries (cf. Otterbeck 2018 for an examination of Sweden in this regard).

One can add that the positions of political identities can be a bit of a movable feast up for persuasive contest and reconfiguration in the right circumstances. My argument, therefore, follows Higgie (2015: 64) in wanting to depart from simple binaries of augmentation or diminution of democracy that are applied when many scholars examine American television satire.

The rebel stance is only a partial view of satire since we know it has a varied history. Following this precept, Condren (2012) warns us against any essentialist or formal definition of satire to be authored by scholarly fiat. At best one can provisionally state that satire is "an idiom of criticism, correction and reform, most readily identifiable by its use of humour" (Condren 
2002: 80). But this is a starting point rather than a destination in the quest for the meaning of satire. Scholarly attention to satire needs to be historically, contextually, rhetorically and hermeneutically informed (Condren 2012).

Certainly, a cursory glance at the history of Charlie Hebdo and a proper respect for the terrible price paid by some staff in 2015 would seem to confirm an anti-authoritarian streak. Moreover, in 2011, the magazine's offices were firebombed after publishing a "Charia Hebdo" issue, using the French word for sharia, in response to the victory of an Islamist party in Tunisia's elections. The magazine was an offspring of the protesting 68ers as were many other leftist and underground publications of the time. So in its ink coursed the instinctive desire to kick the "stupid and mean" (bête et méchant, according to its motto) of the republic, to mock the respectable authorities in the form of "politicians, employers, judges, generals, and clerics," in addition to parents and teachers (McGrogan 2016: 169-170, 176).

However, satirists and comedians can sometimes fight on very safe turf rather than from the subversive fringes. Hebdo sometimes ridiculed the less powerful stereotype of the average, ignorant, arrogant, redneck Frenchman (beauf) and displayed some xenophobic images that "mirror[ed] conventional or reactionary stereotypes" (McGrogan 2016: 173). In so doing Hebdo played without hint of irony to some orthodox and long-standing predispositions embedded in French society. Equally pertinent to this argument are the other occasions when Hebdo attacked Islam. Then, Hebdo conformed to a tradition since the French Revolution of vigilantly patrolling secularism (laïcité) and the freedom of criticising religion as key components of French identity and democracy, and of targeting the church along with the army and the judiciary in vigorous attacks on what were deemed oppressive establishments of power (McGrogan 2016: 168-169). In these cases, Hebdo's humour was not a tool of the oppressed, as it is often conceived, but a tool of the powerful who guarded the social order and its principles against those who objected.

Yet this complicated French context to Charlie Hebdo was understandably discarded in the wake of the massacre during a rush to frame the Hebdo massacre within grand global political categories that elevated it out of the French context. This move had a precedent in the Danish Cartoons saga of 2005-2006 that escalated to global proportions as a cause célèbre of free speech. That spotlight, however, cast a shade over any explanation of the aggressive and moralistic potential of satire. The resulting furore need not have escalated into an international crisis but for the political incompetence of Prime Minister Anders Fogh Rasmussen whose government was mired in local politics and culture war battles and who stubbornly refused to defuse the affair before it became a worldwide fracas (Rolfe 2009).

In this saga, government actions, and the humour it supported, guarded the social order and its principles against those who objected, just as Charlie Hebdo has done on occasions. As Kuipers (2011) and Smith (2009) have argued, humour was again a tool of the powerful, not of the oppressed. Power and hierarchies were subtly reinforced and boundaries between the included (Danish governing parties, media and supporting population) and the excluded (minority Moslems) were severely drawn over the meaning of the humorous and humourless responses to the cartoons. In the process, the unlaughter of objecting Moslems was recast as their own fault and failure to incorporate Danish values. Statements describing Moslems as lacking a sense of humour became powerful accusations of intolerance and fundamentalism.

The tale began when Flemming Rose, editor of the Jyllands-Posten newspaper which had the same right-wing inclinations as the Rasmussen government, commissioned cartoons about Islam because he witnessed incidents of what he called "self-censorship" - such as the refusal of a Danish comedian to pee on the Koran whilst on television - that reminded him of his time in the Soviet Union (Rose 2006). Again, the charge was fear of totalitarianism but this was too easily confused with the conflicting self-censorship and restraint demanded in any society. Rose's initial explanation stands at odds with his later claims during the uproar that he had commissioned the cartoons with the aim of "integrating" and "including" Moslems into Danish 
society rather than treating them as "strangers" (Rose 2006). Up until then, various Danes had done a pretty good job in making the Muslim minority feel unwelcome. This situation was aggravated by the aggressive and exclusionary nature of satire targeting a taboo that could be held only by Moslems.

The publication of the cartoons occurred one week after one of Rasmussen's ministers spoke of a culture war against multiculturalism, relativism and Moslems. In addition two members of the right-wing populist Danish People's Party called Moslems "a cancer on Danish society" in speeches in parliament (Klausen 2006). These events and others prompted moderate Danish Muslim leaders to send a letter to Rasmussen complaining of the "on-going smear campaign" against Islam and Moslems. He refused to meet them and did not respond to their letter (Rynning \& Schmidt 2006). It was an "open secret" in Copenhagen that Pia Kjaersgaard, the leader of the People's Party upon which Rasmussen's government depended, had prohibited the meeting (Séréni 2009). This deliberate inaction was in stark contrast to Rasmussen meeting with Muslim leaders in July after a Danish radio announcer suggested that Moslems should be killed or deported because of the London bombings. As punishment, the government had suspended the licence of the station for 3 months, a clear example of condemnation that Rasmussen did not apply after Kjaersgaard's intervention.

Nevertheless, the matter brewed for several months. Because of the need to placate coalition partners Rasmussen ignored private advice from the French and British governments to deal with the situation, from 22 Danish former ambassadors who protested at the handling, and from his civil service who worried about the consequences (Larsen 2007: 58-60). It was inevitable in January 2006 that the ticking bomb finally blew up with global protests, boycotts and attacks on Danish embassies, all due in no small part to some radical Danish clerics touring various governments in the Middle East with complaints of racism (Spiegel Staff 2006) and to the Egypt and Saudi governments which sought to exploit the Danish mess for their own purposes (Larsen 2007: 55-57).

Still, Rasmussen did not condemn the publication of the cartoons, unlike the right-wing American and Australian governments that carefully balanced support for freedom of speech with denunciation of the cartoons as "offensive" (Rice 2006: 197, 217; Downer 2006). Both the Bush and Howard governments were mired in the Iraq war and wished to simultaneously not offend Muslim minorities in their own countries and to stand for general principles that were revered at home, while distancing themselves from anti-Islamic sentiments that hindered these objectives. These are the sorts of difficult circumstances that governments and public officials often have to navigate due to the responsibilities of office that others, such as garrulous media commentators and public intellectuals, do not have.

Instead, Rasmussen sought partisan advantage through coalition stability and stuck by absolutist declarations of free speech and accusations of misinformation campaign while seeking to drag the Americans and Europeans into the fray. In contrast, they wanted distance from him (Rynning \& Schmidt 2006: 14) and containment of a crisis that he had let develop out of control. In the whole debacle, Rasmussen had abrogated his domestic responsibilities as a national leader who needed to negotiate the difficulties between majorities and minorities.

In the aftermath, Salman Rushdie, Ayaan Hirsi Ali, Bernard-Henri Levy and other writers appended their names to the Manifesto: Together Facing the New Totalitarianism initiated by Caroline Fourest. She published it in Charlie Hebdo where she worked and which republished the Danish cartoons. The declaration very clearly looked to the past struggles against "fascism, Nazism, and Stalinism" as a guide to fighting "a new global threat: Islamism" (BBC 2006a). Consequently, they posed a rhetoric of war, invaders (in the form of Moslems), cowards (in the form of those compromising free speech and liberty), and traitors (in the form of culturally relativist intellectual and political elites who side with Islamism against America and dismiss criticism of Moslems and Islam as racist) (Boe \& Hervik 2008: 218-226). These enemies existed 
across countries in the West. In the process, moderate and radical Muslim complainants to the cartoons tended to be lumped together.

\section{Israeli populism and Holocaust satire}

The Danish Cartoons episode proved how humour could be an aggressive intrusion into complicated identity politics. Other incidents of identity politics between left and right followed this pattern of conflict over satire, offence, free speech and unlaughter that contrasted with absolutist declarations. As was noted at the onset Netanyahu supported free speech after the Hebdo attack. Yet his government was highly critical of satire that crossed its own lines of acceptable speech. Moreover, we can understand how satire, as a moralistic and often aggressive discourse that targets alleged wrongdoers, can distribute moral judgements that may inflame opinions and political sides.

During the first intifada in 1993, a cartoon in the Sydney Morning Herald portrayed shells marked with the Star of David raining on a Palestinian woman running with baby and child. The caption was simply the word "Holocaust." The Israeli ambassador savaged the cartoon as "perverse and a lie" and "a desecration of the memory of the one people who suffered the Holocaust" (Wright 1993). For him, Israeli actions against Palestinians should not be defined with the word holocaust since this equation not only broadened the range of victims of the Holocaust beyond Jews in World War II but also in the process claimed some unacceptable moral equivalence between Jewish and Palestinian suffering. It also posited a moral equivalence between Israelis and Nazis.

Under contest here was the definition of the Holocaust and its application. The act of definition was recognised by Aristotle as a persuasive part of argumentation because "conclusions are drawn upon the subject in question" (Aristotle 1932: 305). Definitions are not inevitable, not always innocent, and are often contested for a definition is "to plead a cause" (Zarefsky 2004: 612). They are propositions that do not deal with the essences of things but with word usage in relation to semantic fields of meanings. This is especially the case with abstractions such as satire, which is defined by reference to a semantic field that includes humour, parody, mockery, ridicule, lampoon and other concepts (Condren 2012: 390). Therefore, when it comes to statements about society and its identity, "definitional disputes should be treated less as philosophical or scientific questions of 'is' and more as socio-political and pragmatic questions of 'ought"' (Schiappa 2003: 3). That is, people may seek to push for or stave off certain words because they have appraisive force that can cast something in "a particular moral light" (Skinner 2002: 167-169) that they may like or dislike. In particular, political concepts are not neutral in their application to a situation. They are judgements that dispense approval or disapproval. So, definitions are not susceptible to simple resolution through a resort to facts because they are battles over values and principles. That is why analogies claiming moral equivalence between Israelis and Nazis were unacceptable and why the limits of free speech had been reached for both Israeli ambassadors.

More specifically, this means that conflict over some humorous event can arise because of different evaluative judgements that are brought to bear by protagonists in their interpretations rather than over an endogenous quality of the event standing as the sole cause. This claim has further exploration later in the article.

For Israeli governments the meaning of the Holocaust is not only a struggle on the international stage but also one on the home front where the Holocaust has been politicised since the late 1940s. Again, we see on this level the devil in the details of free speech. In domestic debate this trauma has often been connected to the Israel-Palestine conflict, the nation's relations with Arab countries, the equation of Arabs with Nazis, and Israel's wars against threats of 
annihilation. That is, the Holocaust is not simply an event of the past but a source of chronic anxiety and danger in the present that contributes to a sense of victimhood in Jewish-Israelis (Steir-Livny 2015). Beginning in the late 1960s but growing from the 1980s was the challenge to these views from some of the left who discounted the elision of Arabs with Nazis and saw instead Israeli military control and administration of Palestinians as similar to Nazi operations and racism.

Since the 1990s the national anxiety has been embroiled in partisanship due to major political changes. The ascendancy in government of Menachem Begin and his Likud Party from 1977 bequeathed a form of right-wing anti-elite populism that has a legatee in Benjamin Netanyahu's terms as prime minister (1996-1999; 2009-present). As embodiments of "the people," both men appealed to those feeling excluded by Ashkenazi and left-wing elites and who distrusted "the media, the civil society, the universities, and especially the judiciary as institutions controlled by small yet powerful left-wing elitist groups that manipulate the rest of society in accordance with their narrow interests" (cited in Weiss Yaniv \& Tenenboim-Weinblatt 2016). Both men and their allies have profited politically from posing a culture war in which these secular elements of Israeli society are deemed inferior, wrong, traitors to religious values, and of "being far too sympathetic toward the Arabs" (Pedhazur 2012: 61; see also Katz 2008). Although nativism was already apparent in this populism, Netanyahu added an exclusionary note with attacks on migrant workers and Arab citizens of Israel. He had been bolstered by an alliance partner Avigdor Lieberman, head of the Israel Beitenu party, and others on the right who are hostile to democracy but not to authoritarianism.

That is the political background to the humorous treatment of the Holocaust in Israeli media and culture since the nineties. However, derision was never directed at the event or at the victims but at the manipulation of the catastrophe by political figures on the right. The comedy Hahamishia Hakamerit (1993-1997) was "the first Israeli TV programme [...] to treat the Holocaust satirically" through depicting Israeli collective memory as presently trapped in "the traumas of the past." The writers of this show and of the comedy Eretz Nehederet ("What a Wonderful Country"; 2003 - present) often mocked the right-wing politicians and other elites of the "Holocaust industry," as one of the writers put it, who cynically manipulated the Holocaust and the sense of victimhood for political advantage (Steir-Livny 2015: 198).

Netanyahu is a notable target of this satiric ire because of his readiness to inject the past catastrophe into the present, particularly his claim that Iran would cause the second Holocaust. His sometime ally Lieberman has been rendered in skits as a Nazi. Both men were constant targets on Hartzufim ("Crappy/Cheeky Faces"; 1996-2000), a satirical programme with puppets in the manner of the British show Spitting Image (Shifman 2012).

Unsurprisingly, this satire has not proved popular with elements of the right who view it in culture war terms as proof of left domination of the media and culture industries. In 2018, according to a newspaper that favours Netanyahu, he was outraged as was Naftali Bennett, who was the target of an Eretz Nehederet skit showing the latter wearing two tefillin, that is, the small leather boxes containing Torah verses. This disrespected "things sacred to Israel" (Swissa 2018), proving he had limits to free speech. That same year Netanyahu attacked the same show for "apparently having no limit to its cynicism or lack of values" in supposedly making light of the Holocaust. This was a partisan ruse. Actually the show mocked a nationally recognised poet for caving to pressure into apologising for comparing a teenage Palestinian activist to Anne Frank. In the skit the show also portrayed Lieberman and another minister discussing treatment of Palestinians and African migrants before "leading the audience in a chorus of 'It's not a Holocaust"” (TOI Staff 2018).

Clearly, the culture war battles in Israel extend to struggles over the acceptable limits of satire and speech but they also extend to the desire among some of the right to have their own, more palatable satire that reinforces their political values. Here, satire is not a mode of the rebellious 
parrhesiaste but a badge of political identity extending into the international sphere and blurring any distinction from the domestic sphere. For Caroline Glick, an American-born columnist of the right wing The Jerusalem Post and former adviser to Netanyahu, the "left commissars" are the ones who "continue leading us by the nose" through Israeli television (Glick 2013). She was the editor of Latma, an Israeli media criticism website that is funded by the right-wing Centre for Security Policy in Washington (Mackey 2010). In 2015, Arutz Sheva - a right-wing news outlet identified with the settler movement - celebrated with the headline "Right-wing Satire Finally Breaks Leftist TV Hold" when "cult-classic Latma" won a spot on national television Channel 1 (Yashar 2015). There the show lasted for 11 episodes as Hakol Shafit ("We'll Be the Judge"). Here humour was an assertion of political identity against opponents rather than an invitation to solidarity. On that note, I turn to Australia.

\section{Australian satire and the culture wars}

Rhetorical manoeuvring for political advantage in the meta-discourse over political humour is also present in the case of satire and free speech surrounding the Israel versus Palestine issue as it figures in Australian politics. A strong component of the Australian meta-discourse over political humour is the partisan, excited and exaggerated hortatory rhetoric that is typical of many representative democracies (see Robertson 1995: 9; Rolfe 2016: chapter 2) but which does not necessarily provide clarity about the concept of free speech. Therefore, this national level of analysis is more complicated due to context, as I have been insisting throughout this article, than simple slogans of absolute freedom of expression. Again we see different evaluative judgements and political identities brought to bear in satiric controversies.

Cartoonist Michael Leunig believes the members of his vocation are "truth speakers" and their role is to stand "up for persecuted minorities whether they be Jews in the 1930s or Palestinians today" (Media Watch 2014). To wit, in 2012 he reworked Martin Niemoller's poetic statement in a cartoon:

First they came for the Palestinians and I did not speak out because I was not Palestinian.

Then they came for more Palestinians and I did not speak out because I feared hostility and trouble.

(Media Watch 2014)

Rather than see Leunig's comments as free speech, the chairman of the B'nai B'rith AntiDefamation Commission condemned the cartoon for "virulent hate-speech" as it was obscene and anti-Semitic to compare Israel to Nazi Germany in its treatment of Palestinians (Narunsky 2012). This accusation was seconded by Andrew Bolt of News Corporation who has found many of Leunig's cartoons to be "viciously anti-Israel" (Bolt 2014) and by Gerard Henderson, another right-wing opponent of the left in the newspaper, The Australian (2014). Henderson (2015) frequently ridicules Leunig as an "in-house leftist" and "Sandalista." Of course Israelis have themselves fought over the comparison for decades but they have not hurled the charge of antiSemitism at each other. Their Semitic commonality marks a difference to other nations like Australia with tainted histories of anti-Semitism. It clearly matters who are the speakers and the targets of jokes (see Lewis 1987). As well, though, accusations of anti-Semitism can issue from partisan motivations in Australia as they did in France and present arguments for limitations to free speech.

As an accompaniment to an article in Fairfax publications in 2014, Glen Le Lievre drew a cartoon suggesting Israelis enjoyed the bombing of Gaza like it was a television show. The

${ }^{1}$ A satiric neologism scorning a leftwing gentrified middle-class professional who wears sandals and admires the Sandinistas of Nicaragua. 
communications minister in the right-wing federal government called it an "anti-Semitic cartoon" while the attorney general said it was like something out of 1930 s Germany because of the stereotype of the Jew that was used. The executive director of the Executive Council of Australian Jewry (ECAJ) echoed these accusations (Media Watch 2014).

As I have maintained throughout, context is needed here. Some of the criticisms of Leunig and Le Lievre need to be viewed in the light of the Australian culture wars that have raged since the early nineties. Then the right-wing Coalition of Liberal and National Parties formulated in opposition a populist language of social unity and cultural crisis that would return them to government under the leadership of John Howard in 1996. The language was more akin to that of the American right than the Israeli religious right in its concern with protecting Mainstream Australia and the traditional nuclear family from the post-modern urban left elites in their bastions of universities, media and public sector who promoted the interests of minorities with a politically correct agenda of multicultural, gender, sexuality, environmental and racial concerns (Rolfe 1998; Boucher \& Sharpe 2008). With time this populist critique extended into the accusation of undermining Western civilisation.

There were of course media allies outside the Coalition purveying these global tropes of right-wing populism and cultivating political identities with an appropriation of the ethos of the satiric parrhesiaste. Again, global links blurred distinctions between the domestic and international spheres. Even with the existence of conservative organs such as The Spectator Australia (an offshoot of the British journal), Sky News (owned by News Corporation) and Quadrant, "The Australian has been at the centre of the media culture wars as part of Rupert Murdoch's global campaign against liberal progressivism" (George 2009: 13) and against the universities, the (private) Fairfax media (as it then was known) and the (public) Australian Broadcasting Corporation (ABC). The Australian is an extension of the right wing News Corporation that owns Fox News in America and is largely owned by the Murdoch family.

One columnist typified many in the News stable with her attacks on the "West's cultural surrender," "multicultural madness," "cultural relativism," and abandonment of Enlightenment values which led "Western appeasers" to knuckle under to Islamic fascists during the Danish cartoons crisis and other episodes (Albrechtsen 2009). This sort of characteristic argument was very comfortable on the global plane where global abstractions of "them versus us" could remind readers of historic struggles against totalitarianism. Similarly, an editorial on Charlie Hebdo by The Australian savaged the "the left-liberal media" in culture war terms:

The real purpose of the Paris massacre was again to instil fear, undermine the established order, inspire other jihadists and weaken the resolve of the West. Whether deliberate or not, one of the most damaging aspects of this atrocity is that it hit our civilisation in a place already shaping as our Achilles Heel - a spineless and growing penchant for political correctness. ... Over recent years, in the face of the perpetually outraged, our pluralistic, democratic and free societies have gradually been yielding on our hard-won freedom of expression.

(Editorial 2015)

This hortatory rhetoric is more comfortable with universal declarations and hyperbolic declarations of Orwellian thought control, totalitarianism, appeasement and censorship tyranny. It rouses evaluative judgements and the tendency to see an opponent as attempting to suppress free speech on a global basis. For instance, one author claimed the "illiberal," "transnational" and "zombie left" engaged in the sort of "world-purifying utopianism" that sanctions the Hebdo massacre as a consequence of fractured societies (Jones 2016).

This mode of rhetoric is most evident in relation to indigenous affairs and a controversial cartoon by Bill Leak in The Australian. This mode, though, included a self-righteousness that allowed columnists for News to find fault with satire that lampooned a national holiday remembering veterans, as we shall see. They were objecting to speech they did not like within 
Australia, objections that sharply contrasted with their more absolute demands for freedom of expression in attacks on the left. They damned objections of the left as totalitarian while their own objections were framed as reasonable.

In July 2016, a documentary aired by the ABC exposed a detention centre in Australia's tropical north that locked up Aboriginal children as young as 10, put 13- and 14-year-olds in solitary confinement for up to two weeks, often without water, and in some cases they were hooded and shackled in chairs. Next day right-wing Prime Minister Turnbull started procedures for a royal commission into youth abuse. This tragedy needs to be understood against the worsening situation since a previous royal commission into Aboriginal deaths in custody 25 years ago, the history of indigenous children stolen from their families by government authorities for much of the twentieth century (for which previous right-wing Prime Minister John Howard refused to officially apologise), the history of frontier massacres, and the racism that has only slowly relaxed its vicious grip in the decades since the 1960s.

Two days after the documentary, Leak's cartoon blamed Aboriginal alcoholic fathers for children who ended up in detention. He was immediately attacked by Aboriginal organisations and individuals as well as by non-Aboriginals, such as the minister for indigenous affairs in the right-wing government, who called him racist (Thompson 2016). Leak's critics judged his humour was punching down against vulnerable Aboriginal adults who have suffered a tragic history. This hardly seemed to be satire taking on the powerful or forming a bond through humour. But his cartoon did draw traditional partisan battlelines over Aboriginal affairs between the right, which sees individual behaviour at fault, and the left, which sees historical injustice since 1788 causing a continuing burden.

Like its American counterparts, the Australian branch of News Corporation is a keen participant in "the culture wars" fight for "truth" against left-wing totalitarianism (for instance, Cater 2016) and proudly appends the label culture warrior to the likes of John Howard (Young 2019), his Coalition colleagues (Mitchell 2019) and public intellectuals of the right (Sammut 2016a). So do other right-wing outlets (Sammut 2016b; Collits 2018; Hargreaves 2018). Unsurprisingly, then, these organisations jumped to Leak's defence against the left and none of them was more trenchant than Andrew Bolt, who has spread his opinions across television, radio, blog and newspapers.

All the Australians who chanted Je Suis Charlie, as far as he was concerned, were liars because of the left-wing persecution of Leak who told the truth about Aboriginal communities from which children need removal (Bolt 2016). Je Suis Bill Leak, shrieked the Institute of Public Affairs (IPA), another prominent organisation on the right that helped found the right-wing Liberal Party in the 1940s (Lesh 2016). For Mark Steyn, a Canadian satirist who is frequently inserted by News Corp into Australian ideological struggles, "the Australian 'human rights' regime and the Charlie Hebdo killers are merely different points on the same continuum." This was a "war on free speech" and an "Orwellian hatefest" that spewed forth from political correctness (Steyn 2016). The Hebdo massacre had new life within the complexities of Aboriginal affairs and a live Bill Leak was now commensurate with the dead Hebdo staff.

For these culture warriors Leak became a martyr to their cause of free speech when an official complaint lodged against the cartoon with the Australian Human Rights Commission (AHRC) alleged that he contravened section 18C of the Racial Discrimination Act (RDA). Here again, we are dealing with the complex details and limits to free expression rather than absolute statements of free speech. The Act states it is unlawful "to offend, insult, humiliate or intimidate another person or a group of people; and the act is done because of the race, colour or national or ethnic origin of the other person or of some or all of the people in the group." This section is a bête noire of the right-wing generally and of the Coalition, The Australian, the IPA, Quadrant and Spectator Australia in particular. Just after the massacre at Hebdo, Bolt (2016), the IPA and others (see Wilson 2015) opined that the Charlie Hebdo magazine could not exist in Australia 
because 18C made the country less free than France. Their assertions were made without any knowledge of France's historic and extensive censorship laws, which include prosecution of Holocaust denial (see Porter 2015). It seems that, like the right in France, the massacre at Hebdo was an excuse for members of the Australian right to ride their political hobbyhorses into the fray (see Hollister 2015). In addition their grand public assertions were made while ignoring section 18D of the RDA, which provides exemptions for justifiable public comment. So it was that after some considerable stress Leak was cleared because of 18D.

The martyrdom of Leak was a real prospect in the minds of these culture warriors because in the previous year the Islamic State had threatened him with a fatwa (i.e. an Islamic legal ruling) calling for his murder. His crime was to publish in an act of solidarity with the massacred Hebdo cartoonists a cartoon of Mohammed. On the advice of counter-terrorism police he went into hiding and extreme security. This was no doubt a horrendous circumstance but it was no justification for Leak to equate the progressive left within Australia to what he described as "the anti-progress force of Islam" and the political correctness driving it "since the seventh century." Islamists had this much in common with "Marxist" progressives and "keyboard warriors of the humourless Left" who constituted the new conservatives. According to him, both groups of authoritarian fundamentalists had "forged a strange alliance" in "a war on humour itself" (Leak 2016). For good measure before a parliamentary committee he damned the AHRC in the same boat as equally authoritarian. Leak was claiming the rebel satiric ethos to his cause of casting the left as the oppressive tyrants.

Against this backdrop of conflict and outrage it is not surprising to find that Leak argued: "Freedom of speech is the freedom to offend, and that means the freedom to offend anyone." Such an argument must surely amuse defamation lawyers who do perceive and adjudicate legal limits. Along the same lines as Leak was a columnist at The Australian who thought that satire should be offensive but also that "satire should have no boundaries" (Jack The Insider 2015). The paradox here is how satire can be offensive if there are no ethical boundaries to offend. Nevertheless, Leak (2016) stayed true to his argument before a parliamentary committee:

\begin{abstract}
As a cartoonist, I run the risk of 'offending' someone, somewhere, every day. [...] Like beauty, 'offence' is very much in the eye of the beholder. It is unlike beauty, however, in that beauty is incontrovertible while offensiveness is not. Offence can never be given; it can only be taken. This is because in order to be offended one must first choose to do so. As a cartoonist I deploy the weapon of humour to make my points. It is my intention to amuse and, usually, thousands of people find my cartoons amusing. I am simply not responsible if one of my cartoons fails to amuse someone, somewhere who chooses to be offended by it instead.
\end{abstract}

There is a tension here between wanting to amuse and wanting to make a point, while skirting the nature of humour that aggressively targets people to make points and also dumping the problem of offence on the target, especially when that happens to be a racial minority that historically suffered abuse. Leak also skirted the desire of satirists to provoke. Like Rose, he is hiding behind the non-serious claims to humour while placing the personal flaws associated with a lack of humour onto opponents, in the manner described by Kuipers (2011) and Smith (2009).

Leak's position was not one condoned by the ECAJ or by various Muslim organisations in their submissions to the parliamentary committee, further complicating the Australian context to free speech. The ECAJ supported sections 18C and D by drawing on John Stuart Mill's distinction between liberty and licence that put limits on free speech otherwise law and order would break down. The ECAJ not only feared the damage to racial and ethnic members of multicultural Australia but also the desensitisation through anti-Semitism, Holocaust denial, abuse of Aboriginals, and other such slurs that could clear the path to violence (ECAJ 2016). Nevertheless, Jewish leaders have been admonished by some News Corp columnists "to rethink and revise their position" (see among others Albrechtsen 2016) or have been deemed complicit 
in "the multicultural lobby, a coalition of the political left and minority activists" (Salter 2014), or have been judged severe disappointments in not repaying political support to Bolt when he was in trouble with the AHRC (Gawenda 2014). It seems the Jewish leaders were complicating partisan positions.

An entrenched position of culture warriors on the right is to see the left as an elite establishment in control of media, universities and culture and to see themselves as underdogs in a cosmic struggle against left-wing totalitarianism. With this in mind, they draw ideological sustenance from the reputation of satire as the rambunctious mode for rebels and underdogs against authoritarians and this ethos sits on their side of the political ledger, as far as they are concerned. For instance, alt-right figure Milo Yiannopoulos has appeared several times on Bolt's television programme. His ethos was explained to Janet Albrechtsen (2019) of The Australian by a visiting conservative American:

The Left has a long history of provocateurs, comedians, performers who trash the Right. That kind of ribald humour directed at conservatives did a lot of damage, making them out as old-fashioned curmudgeons. Milo did the same. Only he aimed at the Left. He made people laugh at the feminists, at Hillary (Clinton). He took their weapon and they couldn't bear to lose it. Now they are the boring puritans.

Despite the arguments of Jews, Moslems and other groups cultural warriors like Bolt were more ready to see section $18 \mathrm{C}$ as the authoritarian handiwork of the PC leftist opponents they credited with the persecution of Leak. Yet the perception of anti-Semitism in adversaries indicated that various commentators did have boundaries to satiric expression despite their universal stands in support of Charlie Hebdo. We can witness their boundaries on other occasions. In 2018 Leunig drew a cartoon depicting military medals as "medals for fear, hate, anger and homicide." As far as Bolt was concerned the Fairfax publication had thereby "trash[ed] Anzac Day," which venerates Australian veterans. He was consoled by a fellow presenter on Sky News, a part-time satirist who also edits the Spectator Australia, who declared Leunig was "beyond repulsive," "nasty," "vindictive" and "not funny" with this drawing. For Leunig to "mock" the people attending memorial ceremonies was "pretty low, pretty despicable" and showed him "incapable of understanding the sacrifice" (Bolt 2018). Similarly a prominent Muslim woman commentator chose Anzac Day to post on Facebook "Lest We Forget" regarding the refugees rejected from Australia and languishing in offshore detention camps. This sparked outrage from a range of Coalition and other right-wing parliamentarians as well as from News Corporation publications, including columnists like Bolt (Ackland 2017; Grattan 2017). These Australian cases exhibit the "patriotic correctness" that a writer at the Cato Institute viewed as the American right's "own version of political correctness" (Nowrasteh 2016). They were offended and, accordingly, objected in line with the meta-discourse of humour.

\section{Conclusion}

Bolt and his political kind are no different to the left they vehemently oppose in having satiric limits that oblige unlaughter. Yet so much of their culture war rhetoric was hyperbolic and partisan in painting opponents as authoritarians or totalitarians. They exaggerated criticism they disliked as some Orwellian threat of political correctness rather than as part and parcel of the meta-discourse of humour. This bolstered political identities. Because of that, their language of absolutes using Charlie Hebdo complicated the already complex area of free speech. Free speech cannot be absolute and independent of any other concerns. Rather, it needs to be judged on a case-by-case basis and in context. Freedom of speech continually jostles with other social goods of a political community, winning on some occasions and losing on others. 
This is not always apparent in discussions of Charlie Hebdo because of the hortatory rhetoric of the culture wars with its partisan and hyperbolic declarations of Orwellian thought control, appeasement, tyranny and PC censorship. Much like their overseas ideological friends, right-wing populists in Australian media tended to lift events out of their local contexts and embed them in a global narrative that dispensed with local causes and complications. In this process of global framing right-wing populists were much like their left-wing counterparts in the global justice movement over the previous twenty years (Tarrow 2005). The meta-discourse about satire was intrinsic to the moralistic framing in culture war rhetoric.

Furthermore, right-wing populists involved in "the cartoon wars" have made connections across the globe in similar ways to recent right-wing networks that had been overlooked by scholars and activists focusing on the global justice movement, claims Clifford Bob (2012). The evidence of such networks, stated Bob, existed in the cross-national alliances of gun ownership organisations and the international "Baptist-Burqa network" of religious conservatives that have challenged international networks for gay rights, women's rights, the death penalty, poverty alleviation, nuclear power, and humanitarian intervention. The international right wing alliances were active opponents of these causes. Consequently, global civil society was a far more ideologically diverse environment than had been conceived till then by those who thought the globe was progressing along a left-wing path to greater democracy, justice and equality.

Nonetheless, the culture warriors in Australia participated in the same way as critics of Leak in the meta-discourse over appropriate humour. Both sides condemned cartoons they did not like with charges of prejudice. Leak thought "letting people express their views in the marketplace of ideas" would sort the chaff of "bad ideas" from the "better ones in an ongoing process" that arrives at the truth (2016). Yet he did not allow that such expression must involve some form of criticism of him and other cartoonists in the meta-discourse that surrounds humour.

The pity is that Leak rejected criticism as authoritarian, as did many of his supporters. Aboriginals in Australia and moderate Moslems in France and Denmark wanted their objections to cartoons to be heard in the same way as culture warriors objected to anti-Semitic cartoons and as one would expect of peoples who perceived aggressive laughter at their expense. Such commentary is a normal part of the meta-discourse of humour. In the wake of the Danish cartoons delegations of moderate Moslems attempted to meet Rasmussen but he rebuffed them because of his intransigent allies. Yet they were denigrated for their criticisms, as were French Moslems and Aboriginal Australians, and for their purported totalitarianism. In that way, hierarchies were being reaffirmed. To be clear, censure is not the same as censorship. Censure and disagreement are intrinsic components of the political conversations that argue over free speech in that marketplace of ideas that Leak shallowly invokes, and that attempt to give some shape to the amorphous and constantly shifting boundaries of acceptable and humorous speech and to the distinctions between laughter and unlaughter. Such conversations connect to the selfrestraint and social standards of taste that are necessary to society but which are inflected with issues of power, inclusion, exclusion, and hierarchy.

\section{References}

Ackland, R. (28 April, 2017). 'The Yassmin Abdel-Magied bash-a-thon is all part of the Anzac Day ritual'. The Guardian. Retrieved May 27, 2019 from https://www.theguardian.com/commentisfree/2017/apr/28/the-yassmin-abdel-magiedbash-a-thon-is-all-part-of-the-anzac-day-ritual 
Abunimah, A. (19 January, 2015). 'France begins jailing people for ironic comment'. Electronic Intifada. Retrieved January 25, 2021 from https://electronicintifada.net/blogs/aliabunimah/france-begins-jailing-people-ironic-comments

Albrechtsen, J. (21 September, 2009). 'Multicultural madness needs such antidotes'. The Australian. Retrieved May 27, 2019 from https://www.news.com.au/news/multiculturalmadness-needs-such-antidotes/newsstory/463397ad8846341aad21e3b74ab13812?sv=aa1d04c240dd0c6794b3d8b11d082a02

Albrechtsen, J. (18 October, 2016). 'Why is a beheading threat okay but a cartoon comment not?'. The Australian. Retrieved May 27, 2019 from https://www.theaustralian.com.au/commentary/opinion/why-is-a-beheading-threat-okaybut-a-cartoon-comment-not/news-story/38185022546bd2f6f5b9721532a7be32

Albrechtsen, J. (13 April, 2019). 'Thinker Mark Bauerlein packs quite a right cross'. The $\begin{array}{lllll}\text { Australian. } & \text { Retrieved } & \text { May } & 27, & 2019\end{array}$ https://www.theaustralian.com.au/inquirer/thinker-mark-bauerlein-packs-quite-a-rightcross/news-story/b61c12a0f6eceba639ac4aa797f4e1e4

Anderson, B. (2006). Imagined Communities: Reflections on the Origin and Spread of Nationalism. Rev ed., London; New York: Verso.

Aristotle. (1932). Art of Rhetoric. Translated by John Henry Freese. London: William Heinemann Ltd.

BBC News. (1 March, 2006a). Writers Issue Cartoon Row Warning. Retrieved May 27, 2019 from http://news.bbc.co.uk/2/hi/europe/4763520.stm

BBC News. (2 November, 2015). Comic Dieudonne Given Jail Sentence for Anti-Semitism. Retrieved May 27, 2019 from http://www.bbc.com/news/world-europe-34921071

Billig, M. (2005). Laughter and Ridicule: Towards a Social Critique of Humour. London: Sage Publications Ltd.

Bob, C. (2012). The Global Right Wing and the Clash of World Politics. New York: Cambridge University Press.

Boe, C. \& Hervik, P. (2008). 'Integration through insult?', in Eide, E., Kunelius, R. \& A. Phillips (eds.), Transnational Media Events: The Mohammed Cartoons and the Imagined Clash of Civilizations, Goteborg: Nordicom, pp. 213-234.

Boler, M. \& Turpin, E. (2008). 'The Daily Show and crossfire: Satire and sincerity as truth to power', in Boler, M. (ed), Digital Media and Democracy: Tactics in Hard Times, Cambridge, MA: MIT Press, pp. 383-403.

Bolt, A. (14 November, 2014). 'Persecuting Leunig for his sweet pictures of wicked Jews'. Herald Sun. Retrieved May 27, 2019 http://www.heraldsun.com.au/blogs/andrewbolt/persecuting-leunig-for-his-sweet-pictures-of-wicked-jews/newsstory/329a566b937b2e190a6fa79b4b594bc2

Bolt, A. (10 January, 2015). 'Are we really all Charlie? No, no and shamefully no'. Herald Sun. Retrieved May 27, 2019 from http://www.heraldsun.com.au/news/opinion/andrewbolt/are-we-really-all-charlie-no-no-and-shamefully-no/newsstory/aa2c9614e8ec08c0e790660db1aaa042

Bolt, A. (19 October, 2016). 'Andrew Bolt on Bill Leak critics: Those supporting Charlie Hebdo free speech strangely quiet'. Herald Sun. Retrieved May 27, 2019 from http://www.heraldsun.com.au/news/opinion/andrew-bolt/andrew-bolt-on-bill-leak-criticsthose-supporting-charlie-hedbo-free-speech-strangely-quiet/newsstory/c4d93811a3c6172af10a712f23557b22

Bolt, A. (25 April, 2018). 'The age trashes Anzac Day'. The Daily Telegraph. Retrieved January 25, 2021 from https://www.dailytelegraph.com.au/blogs/andrew-bolt/the-age-trashesanzac-day/news-story/f4f238cc3716c4b269e4a7e 803f82651 
Boucher, G. \& Sharpe, M. (2008). The Times Will Suit Them: Postmodern Conservatism in Australia. Sydney: Allen \& Unwin.

Bourke, J. (3 August, 2008). “"Anti-Semitic” satire divides liberal Paris'. The Guardian. $\begin{array}{llll}\text { Retrieved } & \text { May } 2019 & \text { from }\end{array}$ https://www.theguardian.com/world/2008/aug/03/france.pressandpublishing

Boycott apartheid. (21 February, 2015). An Interview with Amy Boycott, Israeli Satire Show. $\begin{array}{llll}\text { Retrieved } \quad \text { May } & 2019 & \text { from }\end{array}$ https://www.youtube.com/watch?time continue=3\&v=RzeXggtjDsc

Canovan, M. (1999). 'Trust the People!'. Political Studies, XLVII.

Cater, N. (26 July, 2016). 'Denial of speech is one step towards totalitarianism'. The Australian. Retrieved November 26, 2019 from https://www.theaustralian.com.au/commentary/opinion/denial-of-speech-is-one-steptowards-totalitarianism/news-story/0af4d1a227be69d00dcc8cc179c57c46

Collits, P. (6 August, 2019). 'The corporate scolds of contemporary capitalism'. Quadrant. $\begin{array}{llll}\text { Retrieved November } & 26, & 2019 & \text { from }\end{array}$ https:/quadrant.org.au/opinion/qed/2019/08/contemporary-capitalisms-pc-mania/

Condren, C. (2002). 'Between social constraint and the public sphere: On misreading earlymodern political satire'. Contemporary Political Theory 1, pp. 79-101.

Condren, C. (2012). 'Satire and definition'. Humor: International Journal of Humor Research 25 (4), pp. 375-399.

Davis, J. M. (2016). 'Satire and its constraints: Case studies from Australia, Japan, and the People's Republic of China'. Humor: International Journal of Humor Research 29 (2), pp. 197-221.

Douthat, R. (21 September, 2016). 'Clinton's Samantha Bee problem'. New York Times. $\begin{array}{llll}\text { Retrieved November } & 26, & \text { 2619 }\end{array}$ https://www.nytimes.com/2016/09/21/opinion/campaign-stops/clintons-samantha-beeproblem.html? $\mathrm{r}=0$

Downer, A. (2006). Speech to the National Newspaper Publishers' Conference: Foreign Policy Values and the Media, Gold Coast, 28 August, Department of Foreign Affairs. Retrieved May 27, 2019 from http://www.foreignminister.gov.au/speeches/2006/060828_nnp_conf.html

Editorial. (9 June, 2015). 'Taking offence at the rise of a new Endarkenment'. The Australian. $\begin{array}{llll}\text { Retrieved } & \text { May } & 2019 & \text { from }\end{array}$ https://www.theaustralian.com.au/commentary/editorials/taking-offence-at-the-rise-of-anew-endarkenment/news-story/86900bc03ce9745d5b4ec7e2e3945ecd

Executive Council of Australian Jewry. (2016). ECAJ Submission to Parliamentary Inquiry into Freedom of Speech - Part Iia of the Racial Discrimination Act 1975 (Cth) (Rda) And the Australian Human Rights Commission - 6 December 2016. Retrieved May 27, 2019 from https://www.aph.gov.au/Parliamentary_Business/Committees/Joint/Human_Rights_inquir ies/FreedomspeechAustralia/Submissions

Flood, A. \& A. Yuhas. (27 April, 2015). 'Salman Rushdie slams critics of PEN's Charlie Hebdo tribute'. The Guardian. Retrieved May 27, 2019 from https://www.theguardian.com/books/2015/apr/27/salman-rushdie-pen-charlie-hebdopeter-carey

French, D. (1 May, 2017). 'America's 'smug-liberal problem'. Nation Review. Retrieved November 26, 2019 from https://www.nationalreview.com/2017/05/samantha-bee-bretstephens-smug-liberal-problem-climate-change-debate/

Gawenda, M. (3 April, 2014). 'Why Andrew Bolt's distress is truly uncomfortable'. The Australian.

Retrieved

May

27 ,

2019

from 
https://www.theaustralian.com.au/business/business-spectator/news-story/why-andrewbolts-distress-is-truly-uncomfortable/750b94b0f00eedce7ed31d9331aa2f3d

Glick, C. (13 August, 2013). Best of the Tribal Update, part 1. Retrieved May 27, 2019 from http://carolineglick.com/best-of-the-tribal-update-part-1/

George, J. (2009). 'Introduction: are the culture wars over?', in George, J. and K. Huynh (eds), Culture Wars: Australian and American Politics in the $21^{\text {st }}$ Century, George, Jim \& Kim Huynh South Yarra: Palgrave Macmillan.

Grattan, M. (26 April, 2017). 'Abdel-Magied Anzac row is a storm over not much'. The Conversation. Retrieved May 27, 2019 from https://theconversation.com/abdel-magiedanzac-row-is-a-storm-over-not-much-76708

Hargreaves, S. (2018). 'A culture war and peace'. Institute of Public Affairs. 1 October. Retrieved November 26, 2019 https://ipa.org.au/ipa-review-articles/a-culture-war-andpeace

Heer, J. (8 September, 2015). 'Donald Trump's comedic genius'. New Republic. Retrieved November 26, 2019 from https://newrepublic.com/article/122738/donald-trumps-comedicgenius

Hemingway, M. (11 November, 2016). 'How Jon Stewart and "The Daily Show" Elected Donald Trump'. The Federalist. Retrieved November 26, 2019 from https://thefederalist.com/2016/11/11/how-jon-stewart-and-the-daily-show-elected-donaldtrump/

Henderson, G. (29 May, 2015). 'Media Watch Dog: Leunig; Q\&A inquiry; Manne; The Saturday Paper'. The Australian. Retrieved May 27, 2019 from https://www.theaustralian.com.au/commentary/opinion/media-watch-dog-leunig-qampainquiry-manne-the-saturday-paper/news-story/af79b3b2135d89218fc78309d566e1f5

Higgie, R. (2015). 'Playful politicians and serious satirists: Comedic and earnest interplay in Australian political discourse'. Comedy Studies 6 (1), pp. 63-77.

Hollister, L. (10 January, 2015). 'We are all Charlie Hebdo - or are we?'. The Conversation. Retrieved May 27, 2019 from https://theconversation.com/we-are-all-charlie-hebdo-or-arewe-36044

Intelligence Squared. (13 October, 2016). PJ O'Rourke on why you shouldn't mock Trump $\begin{array}{lllll}\text { supporters. } & \text { Retrieved } & \text { November } & 2019, & \text { from }\end{array}$ https://www.youtube.com/watch?v=DWLRwPRq75c

Jack The Insider. (17 December, 2015). 'Bill Leak cartoon furore shows satire should have no boundaries'. The Australian. Retrieved May 27, 2019 from http://www.theaustralian.com.au/opinion/blogs/bill-leak-cartoon-furore-shows-satireshould-have-no-boundaries/news-story/85850f06558b95e457cbf763c4434645

Jones, D. (15 August, 2016). 'The illiberal left and political Islam'. Quadrant Online. Retrieved May 27, 2019 from https://quadrant.org.au/magazine/2016/07-08/illiberal-left-risepolitical-islam/

Jordan, M. (2008). 'Thinking with Foucault about truth-telling and The Daily Show'. The Electronic Journal of Communication: Irony and Politics 18 (2, 3, and 4), Boler, M. \& Gournelos, T. (eds). Retrieved January 20, 2021 from http://www.cios.org/www/ejc/v18n24toc.htm

Katz, G. (2008). 'The Israeli kulturkampf'. Israel Affairs 14 (2), pp. 237-254.

Klausen, J. (8 February, 2006). 'Cartoon Jihad: Rotten judgment in the state of Denmark'. Der Spiegel. Retrieved May 27, 2019 from https://www.spiegel.de/international/cartoon-jihadrotten-judgment-in-the-state-of-denmark-a-399653.html

Kuipers, G. (2011). 'The politics of humour in the public sphere: Cartoons, power and modernity in the first transnational humour scandal'. European Journal of Cultural Studies, 14 (1), pp. 63-80. 
Larsen, H. (2007). 'The cartoons crisis in Danish foreign policy: A new balance between the EU and US?'. In N. Hivdt \& H. Mouritzen (eds.), Danish Foreign Policy Yearbook 2007, Copenhagen: Danish Institute for International Studies, pp. 51-86.

Leak, B. (17 December, 2016). '18C: Offence no defence for silencing disagreeable opinion'. The Australian. Retrieved May 27, 2019 from https://www.theaustralian.com.au/nation/inquirer/18c-offence-no-defence-for-silencingdisagreeable-opinion/news-story/798103462ad1b15d1d74623e4b696d72

Lesh, M. (20 October, 2016). 'Je Suis Bill Leak'. Institute of Public Affairs. Retrieved May 27, 2019 from http://ipa.org.au/news/3569/je-suis-bill-leak

Lewis, P. (1987). 'Joke and anti-joke: Three Jews and a blindfold'. Journal of Popular Culture 21 (1), pp. 63-73.

Mackey, R. (4 June, 2010). 'Israelis explain, and mock, flotilla clash'. The Lede. Retrieved May 27, 2019 from http://thelede.blogs.nytimes.com/2010/06/04/israelis-explain-and-mockflotilla-clash/? $\mathrm{r}=0$

McGrogan, M. (2016). 'The politics of provocation: Charlie Hebdo, then and now'. Contemporary French Civilisation 41, pp. 167-195.

Media Watch. (11 August, 2014). 'Bullying, abuse and free speech'. Australian Broadcasting $\begin{array}{lllll}\text { Corporation. } & \text { Retrieved } & \text { May } & 2019 & \text { from }\end{array}$ http://www.abc.net.au/mediawatch/transcripts/s4065281.htm

Mitchell, C. (4 November, 2019). 'High-profile lefties add weight to conservative concerns about campuses'. The Australian. Retrieved November 26, 2019 from https://www.theaustralian.com.au/business/media/highprofile-lefties-add-weight-toconservative-concerns-about-campuses/news-story/4414b650d7192c03b67c5995eec56efe

Narunsky, G. (30 November, 2012). 'The age defends cartoons'. The Australian Jewish News. Retrieved May 27, 2019 from http://www.jewishnews.net.au/the-age-defendscartoons/28575

Nowrasteh, A. (7 December, 2016). 'The right has its own version of political correctness. It's just as stifling'. The Cato Institute. Retrieved November 26, 2019 from https://www.cato.org/publications/commentary/right-has-its-own-version-politicalcorrectness-its-just-stifling

Otterbeck, J. (2018). 'Islam in satire: Representations, taste cultures, and liquid racism', in E. Polyakov (ed.) Antisemitism, Islamophobia, and Interreligious Hermeneutics. Boston: Brill Rodopi, pp. 157-174.

Pedahzur, A. (2012). The Triumph of Israel's Radical Right. New York, NY: Oxford University Press.

Phiddian, R. (2019). Satire and the Public Emotions. Cambridge: Cambridge University Press.

Porter, A. (15 January, 2015). 'Speech in France is not so free as Section 18C critics would have it'. The Conversation. Retrieved May 27, 2019 from https://theconversation.com/speechin-france-is-not-so-free-as-section-18c-critics-would-have-it-36244

Reeve, E. (17 June, 2015). 'Donald Trump is America's most gifted political satirist'. New Republic. $\quad$ Retrieved November $\quad 26, \quad 2019$ from https://newrepublic.com/article/122047/donald-trump-americas-most-gifted-politicalsatirist

Rice, C. (2006). 'U.S. accuses Syria of obstructing Hariri assassination investigation; Danish cartoon enrages Moslems, embassies are burned in Syria; Rice discusses transformational democracy'. Foreign Policy Bulletin 16 (4).

Robertson, A. (1995). The Language of Democracy: Political Rhetoric in the United States and Britain 1790-1900. Charlottesville: University of Virginia Press.

Rolfe, M. (2009). 'Clashing taboos: Danish cartoons, the life of Brian and public diplomacy'. The Hague Journal of Diplomacy 4 (3), pp. 261-281. 
Rolfe, M. (2016). The Reinvention of Populist Rhetoric in the Digital Age: Insiders and Outsiders in Democratic Politics. London: Palgrave MacMillan.

Rose, F. (19 February, 2006). 'Why I published those cartoons'. Washington Post. Retrieved May 27, 2019 from http://www.washingtonpost.com/wpdyn/content/article/2006/02/17/AR2006021702499_pf.html

Rynning, S. \& Schmidt, C. (2006). 'Muhammad cartoons in Denmark: From freedom of speech to Denmark's biggest international crisis since 1945'. UNISCI Discussion Papers 11. $\begin{array}{llll}\text { Retrieved } & \text { May } & 27, & \text { from }\end{array}$ http://revistas.ucm.es/index.php/UNIS/article/viewFile/UNIS0606230011A/28094

Salter, F. (28 March, 2014). 'Section 18C, multiculturalism and power'. Quadrant Online. Retrieved May 27, 2019 from https:/quadrant.org.au/opinion/qed/2014/03/section-18cmulticulturalism-power/

Sammut, J. (9 February, 2016a). 'John Hirst: culture warrior shaped future through the past'. The Australian. Retrieved November 26, 2019 from https://www.theaustralian.com.au/commentary/opinion/john-hirst-culture-warrior-shapedfuture-through-the-past/news-story/1fbf15bdb645edd400dc3b4c63df3dd6

Sammut, J. (9 February, 2016b). 'John Hirst: Culture warrior shaped future through the past'. The Centre for Independent Studies. Retrieved November 26, 2019 from https://www.cis.org.au/commentary/articles/john-hirst-culture-warrior-shaped-futurethrough-the-past/

Samuel, H. (27 January, 2009). 'French cartoonist Siné on trial on charges of anti-Semitism over Sarkozy jibe'. The Telegraph. Retrieved May 27, 2019 from http://www.telegraph.co.uk/news/worldnews/europe/france/4351672/French-cartoonistSine-on-trial-on-charges-of-anti-Semitism-over-Sarkozy-jibe.html

Schama, S. (8 January, 2015). 'Liberty and laughter will live on'. Financial Times. Retrieved May 27, 2019 from https://www.ft.com/content/5ac371cc-9695-11e4-a83c00144feabdc0\#axzz3OBbXKMQc

Schiappa, E. (2003). Defining Reality. Carbondale \& Edwardsville: Southern Illinois University.

Séréni, J.-P. (2009). 'Something rotten in the welfare state of Denmark'. Le Monde Diplomatique, English edition. Retrieved January 25, 2021 from https://mondediplo.com/2009/11/08denmark

Shifman, L. (2012). 'Satire in the holy wonderland: The comic framing of Arab leaders in Israel'. Popular Communication, 10 (1-2), pp. 94-105.

Skinner, Q. (2002). Visions of Politics: Regarding Method, Vol. 1. Cambridge: Cambridge University Press.

Smith, M. (2009). 'Humour, unlaughter, and boundary maintenance'. The Journal of American Folklore 122 (484), pp. 148-171.

Spiegel Staff. (1 February, 2006). 'Alienated Danish Moslems sought help from Arabs'. Spiegel $\begin{array}{lllll}\text { Online, } & \text { Retrieved } & \text { May } & 27, & 2019\end{array}$ http://www.spiegel.de/international/0,1518,398624,00.html

Steir-Livny, L. (2015). 'Holocaust humour, satire, and parody on Israeli television'. Jewish Film \& New Media 3 (1), pp. 193-219.

Steyn, M. (19 October, 2016). 'Bill Leak cartoon: The war on free speech has just begun'. The $\begin{array}{lllll}\text { Australian. } & \text { Retrieved } & \text { May } & 279 & \text { from }\end{array}$ http://www.theaustralian.com.au/news/inquirer/the-war-on-free-speech-has-justbegun/news-story/6c681be69396a311c97b4996888a2f9c

Swissa, E. (18 May, 2018). 'PM, top politicians outraged by satire show for mocking tefillin'. Israel Hayom. Retrieved May 27, 2019 from https://www.israelhayom.com/2018/05/18/pm-top-politicians-outraged-by-satire-showfor-mocking-tefillin/ 
Tarrow, S. (2005). The New Transnational Activism. New York: Cambridge University Press. Kindle Edition.

Thompson, J. (2 November, 2016). 'What is racism - and is Bill Leak a 'controversialist' or a racist?'. The Conversation. Retrieved May 27, 2019 from https://theconversation.com/what-is-racism-and-is-bill-leak-a-controversialist-or-a-racist$\underline{67993}$

Tiboris, M. \& Schaff, K. (2009). 'The WØRD: Fearless speech and the politics of language', in Schiller, A. (ed.), Stephen Colbert and Philosophy: I am Philosophy (And so Can You!), Chicago: Open Court, pp. 115-130.

TOI Staff. (3 February, 2018). 'Netanyahu pans satirical TV show over sketch that upset Holocaust survivor'. The Times of Israel. Retrieved May 27, 2019 from https://www.timesofisrael.com/netanyahu-pans-satirical-tv-show-over-sketch-that-upsetholocaust-survivor/

Turgis, C. (17 January, 2015). 'Charlie Hebdo: à Nantes, un adolescent de 16 ans poursuivi pour "apologie du terrorisme" sur Facebook'. France TV. Retrieved 20 January 2021 https://france3-regions.francetvinfo.fr/pays-de-la-loire/2015/01/17/charlie-hebdo-nantesun-adolescent-de-16-ans-poursuivi-pour-apologie-du-terrorisme-sur-facebook634720.html

Walker, P., Blight, G., Hecimovic, A., \& Blason, J. (13 January, 2015). 'Paris unity march: which world leaders are really committed to press freedom?'. The Guardian. Retrieved May 27, 2019 from https://www.theguardian.com/world/ng-interactive/2015/jan/13/charliehebdo-attack-world-leaders-paris-press-freedom

Warner, Jamie. (2010). 'The Daily Show and the politics of truth', in Dale, T. (ed.), Homer Simpson Marches on Washington: Dissent through American Popular Culture, Lexington KT: University Press of Kentucky, pp. 37-58.

Watt N., Mason, R., \& Traynor, I. (13 January, 2015). 'David Cameron pledges anti-terror law for internet after Paris attacks'. The Guardian. Retrieved May 27, 2019 from https://www.theguardian.com/uk-news/2015/jan/12/david-cameron-pledges-anti-terrorlaw-internet-paris-attacks-nick-clegg

Wilson, J. (15 January, 2015). 'Charlie Hebdo could be published in Australia. And other reasons the 18C debate is a furphy'. The Guardian Australia. Retrieved May 27, 2019 from https://www.theguardian.com/commentisfree/2015/jan/15/charlie-hebdo-could-bepublished-in-australia-and-other-reasons-the-18c-debate-is-a-furphy

Wintour, A. T. P. \& E. MacAskill (2015). 'Theresa May unveils UK surveillance measures in wake of Snowden claims'. 4 November. The Guardian. Retrieved May 27, 2019 from https://www.theguardian.com/world/2015/nov/04/theresa-may-surveillance-measuresedward-snowden

Wright, T. (3 August, 1993). 'Fischer ignorant of Mid-East, says envoy'. Sydney Morning Herald. p. 7.

Weiss Yaniv, N. \& Tenenboim-Weinblatt, K. (2016). 'Israel: Right-wing populism and beyond', in T. Aalberg, F. Esser, C. Reinemann, J. Strömbäck, \& C. H. de Vreese (eds.) Populist Political Communication in Europe. New York: Routledge.

Yashar, A. (6 February, 2015). 'Right-wing satire finally breaks leftist TV hold'. Arutz Sheva. $\begin{array}{llll}\text { Retrieved May } & 27, & \text { from }\end{array}$ http://www.israelnationalnews.com/News/News.aspx/191018

Young, G. (7 May, 2019). 'Folau issue leaves Libs mid-field, as free speech curbs reflect Labour's culture war wins'. The Australian. Retrieved November 26, 2019 from https://www.theaustralian.com.au/nation/politics/folau-issue-wrongfoots-morrison-buthoward-would-have-nailed-it/news-story/809ca8a94746bdec5cd7fced4dc08acb 
Zarefsky, D. (2004). 'Presidential rhetoric and the power of definition', Presidential Studies Quarterly 34 (3), pp. 607-619.

Zekavat, M. (2017). Satire, Humour and the Construction of Identities. Amsterdam/Philadelphia: John Benjamins Publishing Company. 